Letter to Editor

\section{Alone in the face of adversity}

\author{
Francisco Javier Torres-Gómez* \\ Pathologist, High Resolution Hospital, Utrera, Sevilla, Spain
}

\section{Dear sir,}

From my desk I could be watching the wind blow or the horses running. Practicing Medicine in a rural setting has these advantages: from time to time you can take the time to admire the beauty that surrounds you in the form of an obligatory pause within a marathon working day, and rest helps refresh your mind of prejudices to continue with the inescapable task that awaits us after a few minutes, the only ones allowed to order our thoughts.

Do not imagine that I am an idle doctor. Quite the opposite. I am a pathologist in a hospital with high diagnostic resolution and the field is only an illusion, a desire because I am continuously required by the microscope, which calls me to order. So many cases require my attention that I hardly have time to breathe. The responsibility weighs on my conscience and I try to appear cold before the difficult decisions that I must make, almost all of them of great therapeutic importance. I am the hands of my surgical partner, the brain of my clinical partner, and I find myself alone and helpless in the situation in which I find myself. The number of compromised diagnoses has grown so much that there is hardly time left to study. The Pandemic has reduced health workers not only at the front of that famous front line of battle but also in the second and third ranks, as important to safeguarding health as the first ones on the list. The fear of the population to go to hospitals has had undeniable health consequences and many have been silenced. The number of cancer diagnoses has grown exponentially, in a way that is not parallel to the number of specialist medical staff, who many times are overwhelmed and impotent, as well as surprised by the alarming figures we handle. The morbidity and mortality of the virus are indisputable, as are the numbers associated with neoplasms, many of them diagnosed at the wrong time, in advanced stages in which the possibilities of treatment diminish and the associated prognoses are poor.

The pathologist, that invisible medical specialist because he is not mediatic, is alone in the face of adversity. With more than limited resources, he displays tenacity and humility and multiplies himself so that no patient is left without a diagnosis

\author{
More Information \\ *Address for Correspondence: \\ Dr. Francisco Javier Torres-Gómez, Pathologist, \\ High Resolution Hospital, Avda, Brigadas \\ Internacionales s/n. 41710, Utrera, Sevilla, \\ Spain, Tel: 34+629344869; \\ Email: javiertorresgomez@yahoo.es \\ Submitted: February 19, 2021 \\ Approved: March 02, 2021 \\ Published: March 03, 2021 \\ How to cite this article: Torres-Gómez FJ. Alone \\ in the face of adversity. Arch Cancer Sci Ther. \\ 2021; 5: 001-001. \\ DOI: 10.29328/journal.acst.1001022 \\ Copyright: @ 2021 Torres-Gómez FJ. This \\ is an open access article distributed under \\ the Creative Commons Attribution License, \\ which permits unrestricted use, distribution, \\ and reproduction in any medium, provided the \\ original work is properly cited. \\ Check for updates \\ O OPEn Access
}

in time, and that is his commitment to society. Few people know him, and those who do discover his way of working.

There are not good times for Health, but it is essential to study and adapt to the times, be prepared, trained, innovate and apply knowledge, but all this takes time, a time that has disappeared ... And we do not know if it will return.

Still not knowing the impact that the global economic crisis will have on the diagnostic and therapeutic weapons used until now, the pathologist continues to sit at his table, pampering his most faithful ally, the microscope, and with it he draws up an action plan that we can that of the one to diagnose all the possible cases until fainting. That is your calling. And if circumstances permit, you can turn your head in an attempt to discover the beauty that surrounds us, at least as long as it does not die.

As a pathologist, I send a lot of encouragement to patients and health workers who, like me, continue to work in anonymity to achieve a better world, a reality parallel to the pandemic that is ravaging us, with which there are obvious links, but I warn of the danger exists if the media virus makes us forget that chronic diseases cancer are more present than ever and that if we do not reinforce our rear, the defeat may be complete and fatal. 